\title{
APPLE POMACE POWDER AS NATURAL FOOD INGREDIENT IN BAKERY JAMS
}

\author{
B. Szabó-Nótin*, R. Juhász, J. Barta and M. StéGER-MátÉ \\ Department of Food Preservation, Faculty of Food Science, Corvinus University of Budapest, \\ H-1118, Budapest, Villányi út 29-43. Hungary
}

(Received: 14 April 2014; accepted: 25 July 2014)

\begin{abstract}
The aim of the present study was to investigate whether apple pomace powder produced by a simple drying method is suitable for replacing pectin in bakery jam products. Rheological properties of bakery jams were tested by oscillatory tests using amplitude sweep method. Apple pomace addition decreased gel strength and stability of bakery jams, while 12-month storage increased the gel strength of samples. Based on our results, dried apple pomace powder seems to be suitable to replace pectin up to $40 \%$ without changing rheological properties of bakery jams.

Keywords: apple pomace, bakery jam, rheology, texture
\end{abstract}

Jam is a low moisture food prepared by boiling fruit pulp with sugar, pectin, acid, and other ingredients: preservative, colouring, and flavouring agents (BAKER et al., 2005), with total soluble solids content between 50-60\% and at least 45\% fruit content (CODEX Alimentarius, 2009). Bakery jams can be extruded or applied to a pastry, bakery product, or dough and exposed to temperatures of $200{ }^{\circ} \mathrm{C}$ or greater without any detrimental effect on its texture quality (Christensen et al., 2008). The fundamental difference between jams, fruit preparations, and bakery jams during the manufacturing is the gelation, which can be influenced by gelling agents (JAVANMARD \& ENDAN, 2010). Pectin is the most widely used food additive (E 440) for texture modification of fruit containing products. Its properties can be affected by origin, chain length, amount of methylated carboxyl-groups, etc.

Apple pomace, a cheap by-product of apple juice production is rich in pectin, antioxidants, and flavour compounds. It could be used for several applications, such as pectin recovery (Schieber et al., 2003), jam and jelly production (RoYer et al., 2006), enzyme production (FAVELA-TORRES et al., 2006), animal feed, organic acid production (SHOJAOSADATI \& BABAEIPOUR, 2002), ethanol production, as a source of aroma compounds, and natural antioxidants (Foo \& Lu, 1999). Due to its high pectin content, apple pomace could be used as a natural texture modifier in food products after a simple drying process.

Since texture is one of the most important determining factors for the acceptability of food (NiSHINARI, 2009), several rheological methods are developed for direct evaluation of food texture with high reproducibility. Bakery jams are semi-solid viscoelastic materials that have to be 1) easily proportioned by a pump into bakery products; 2) solid in rest (in the box or in the dough); 3) soft when consumed. These properties could be tested by oscillatory techniques, which are useful for determining both the viscous and elastic properties (storage and loss modulus, respectively) of viscoelastic materials (ie. gels, semi-solid and solid materials) (Mezger, 2006; Figura \& Teixeira, 2007), and can be used for testing several

* To whom correspondence should be addressed.

Phone: +36-1-482-6036; fax: +36-1-482-6327; e-mail: beatrix.notin@uni-corvinus.hu

0239-3006/\$ 20.00 C 2014 Akadémiai Kiadó, Budapest 
emulsion or gel food products (Gunasekaran \& Mehmet, 2000; Juhász et al., 2011; Vajda et al., 2013).

The aim of the present study was to investigate the effect of addition of apple pomace powder produced by a simple drying method on the rheological properties of bakery jams.

\section{Materials and methods}

\subsection{Materials}

Raw materials of bakery jams were as follows: apple, apricot, sour cherry, and plum puree (20-20\%) and black currant concentrate (20\%) (Sió-Eckes Ltd., Hungary). Apple pomace was produced under laboratory circumstances using apple cultivar 'Idared' (Orchard of Soroksár, Corvinus University of Budapest). Apple was chopped and pressed using a stainless steel manual press. After pressing, the obtained apple pomace (including skin, core, and kernel) was dried at $80{ }^{\circ} \mathrm{C}$ until $5 \%$ wet content. Dried apple pomace was grinded by a laboratory grinder and sieved through a $0.2 \mathrm{~mm}$ sieve producing apple pomace powder (AP) for the experiments. Industrial bakery pectin (pectin ester) and preservative (potassium sorbate) were purchased from Pacific Óceán Ltd. (Vác, Hungary).

\subsection{Sample preparation}

The preparation of bakery jams was performed according to Table 1.

Table 1. Ingredients of bakery jams

\begin{tabular}{|c|c|c|c|c|c|c|}
\hline Sample & $\begin{array}{c}\text { Fruit content } \\
\qquad(\mathrm{g})\end{array}$ & $\begin{array}{l}\text { Sugar } \\
(\mathrm{g})\end{array}$ & $\begin{array}{c}\text { Preservative } \\
\text { (g) }\end{array}$ & $\begin{array}{l}\text { Pectin } \\
(\mathrm{g})\end{array}$ & $\begin{array}{l}\text { AP } \\
(\mathrm{g})\end{array}$ & $\begin{array}{c}\text { AP content } \\
(\%)\end{array}$ \\
\hline Control & \multirow{6}{*}{550} & \multirow{6}{*}{565} & \multirow{6}{*}{1} & 13 & 0 & 0 \\
\hline $\mathrm{AP}_{40}$ & & & & 12 & 8 & 40 \\
\hline $\mathrm{AP}_{50}$ & & & & 10 & 10 & 50 \\
\hline $\mathrm{AP}_{60}$ & & & & 8 & 12 & 60 \\
\hline $\mathrm{AP}_{80}$ & & & & 6 & 14 & 80 \\
\hline $\mathrm{AP}_{100}$ & & & & 0 & 20 & 100 \\
\hline
\end{tabular}

AP: apple pomace

The procedure was the following: raw materials and $90 \%$ of sugar were mixed and heated up to $80{ }^{\circ} \mathrm{C}$ to completely dissolve the sugar. Pectin and apple pomace powder with a little amount of sugar $(10 \%)$ were dispersed in preheated water $\left(80^{\circ} \mathrm{C}\right)$ and added to the preheated $\left(80{ }^{\circ} \mathrm{C}\right)$ fruit pulp with sugar. Then $1 \%$ preservative (potassium sorbate) was poured into the mixture. The whole mixture was boiled until obtaining $60 \%$ water soluble dry material content. Then $\mathrm{pH}$ was adjusted into the range of 3.0-3.2 using citric acid. The final mixture was boiled for $2 \mathrm{~min}$. Plastic containers of $200 \mathrm{ml}$ were filled with the obtained jam at $80{ }^{\circ} \mathrm{C}$ and closed. Total soluble solids contents of the finished bakery jams were $61.1 \pm 1.0 \%$, 
and fruit content was 55\%. Storage of bakery jams was performed at room temperature $\left(22{ }^{\circ} \mathrm{C}\right)$ for 12 months. Rheological measurements were carried out in every $4^{\text {th }}$ month.

\subsection{Rheological measurements}

Rheological measurements were performed using a Physica MCR 51 rheometer (Anton-Paar $\mathrm{GmbH}$., Graz, Austria). Results were recorded and analysed using Rheoplus software ver. 3.2 (Anton-Paar GmbH., Graz, Austria).

Oscillation tests were performed by a plate and plate measurement system that consists of a P-PTD200 plate and a PP50/S (plate, $50 \mathrm{~mm}$ in diameter) measuring bob with $3 \mathrm{~mm}$ gap size. The amplitude sweep method was carried out at $20{ }^{\circ} \mathrm{C}$, increasing strain value from 0.5 to $200 \%$, at constant angular frequency $\left(10 \mathrm{rad} \mathrm{s}^{-1}\right)$, using five replicates per sample. The samples were changed after each parallel measuring in order to avoid the change in rheological properties.

Amplitude sweep rheograms (storage modulus $\left(\mathrm{G}^{\prime}, \mathrm{Pa}\right)$ and loss modulus $\left(\mathrm{G}^{\prime}, \mathrm{Pa}\right)$ in function of shear stress $(\mathrm{t}, \mathrm{Pa})$ ) of the samples were recorded. Based on the rheograms the following parameters were determined: 1) $\mathrm{G}_{0}{ }_{0},(\mathrm{~Pa})$ : initial storage modulus; 2) $\mathrm{G}_{0}{ }_{0}(\mathrm{~Pa})$ : initial loss modulus; 3) DF: damping factor, the ratio of initial loss modulus to initial storage modulus; 4) $t_{\mathrm{LVE}}(\mathrm{Pa})$ : shear stress at the end of linear viscoelastic range, which is the strain at storage modulus decreased to $95 \%$ of its initial value; 5) $t_{\mathrm{CO}}(\mathrm{Pa})$ : shear stress at crossover point of G' and G' curves, which indicates the turning point between viscoelastic solid and liquid (MEZGER, 2006).

\subsection{Statistics}

Statistical evaluation of measured data was performed using Microsoft Excel software (MS Office 2010, Microsoft Magyarország Ltd., Budapest, Hungary). Effect of the amount of AP powder and storage time on amplitude sweep parameters were analysed by analysis of variance (ANOVA) at 95\% significance level. Difference between the rheological parameters of the different composition samples and the consecutive samplings were analysed by Student's $t$-test at 95\% significance level.

\section{Results and discussion}

\subsection{Effect of replacement of pectin with apple pomace powder}

Gel-like behaviour could be characterized by G' to G' ratio between 1 and 100 (MezGer, 2006), which was achieved in all samples tested. All the bakery jams formed a stiff gel immediately after preparation, as was indicated by higher $G^{\prime}{ }_{0}$ than $G^{\prime}{ }_{0}$ values at 0 . month. (Fig. 1.) However, in case of $A_{100}$ at 0 . month, G' was slightly greater than $G^{\prime}$ indicating its flowable weak gel characteristics.

Amplitude sweep rheograms of all bakery jams (Fig. 1) could be characterized by similar shape including an initial phase with constant $G$ ' and $G$ " values, then a decreasing phase, and finally a crossover point. 

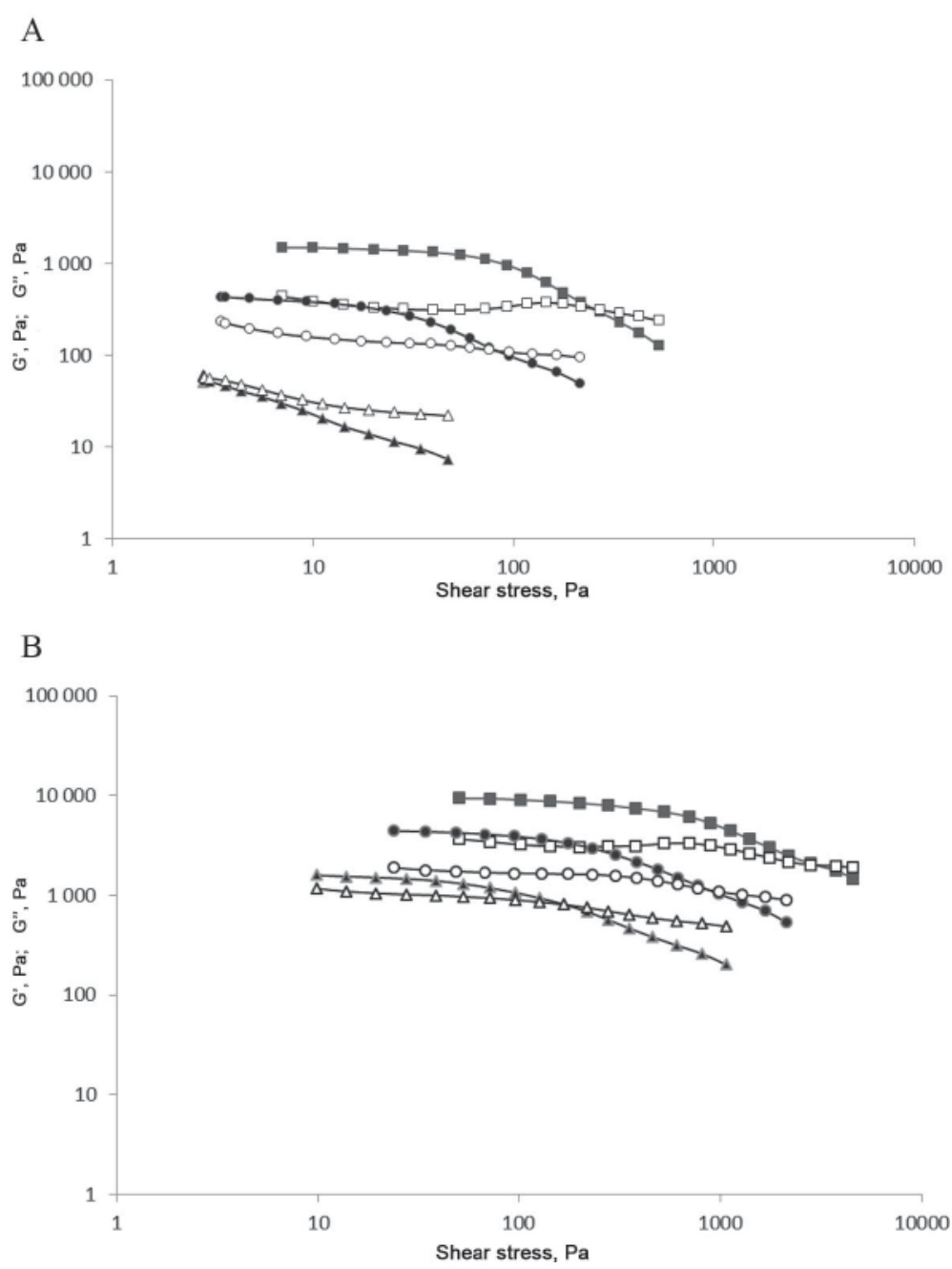

Fig. 1. Amplitude sweep rheograms of bakery jams made of different levels of apple pomace A: Amplitude sweep rheograms at $0^{\text {th }}$ month; B: Amplitude sweep rheograms at $12^{\text {th }}$ month

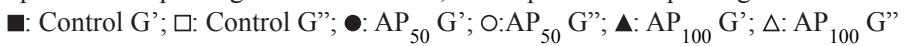

Increasing amount of AP did not affected the shape of the amplitude sweep rheograms, though the G' and G' values decreased compared to the control. (Fig. 1A) Sample AP proved to be the most similar in shape to the reference.

Main parameters of amplitude sweep rheograms are shown in Table 2. According to the ANOVA results, amount of AP powder and storage time had significant effect on amplitude sweep parameters.

Initial value of storage $\left(\mathrm{G}_{0}{ }_{0}\right)$ and loss $\left(\mathrm{G}^{\prime}{ }_{0}\right)$ modulus decreased with the increasing amount of apple pomace powder, though there was no significant difference between either $\mathrm{G}^{\prime}{ }_{0}$ or $\mathrm{G}^{\prime}{ }_{0}$ of $\mathrm{AP}_{40}$ and control, and between $\mathrm{AP}_{50}$ and $\mathrm{AP}_{80} . \mathrm{G}^{\prime}{ }_{0}$ describes the solid-body-like behaviour of the material tested and correlates to stiffness. $\mathrm{G}^{\prime \prime}{ }_{0}$ represents viscous flow behaviour and describes flow ability of materials. 
Table 2. Rheological parameters of bakery jams containing apple pomace based on amplitude sweep rheogram during 12 -month storage

\begin{tabular}{|c|c|c|c|c|c|}
\hline & $\mathrm{G}_{0}^{\prime}(\mathrm{Pa})$ & $\mathrm{G}_{0}{ }_{0}(\mathrm{~Pa})$ & $\mathrm{DF}$ & $\tau_{\mathrm{LVE}}(\mathrm{Pa})$ & $\tau_{\mathrm{CO}}(\mathrm{Pa})$ \\
\hline & $\mathrm{X} \pm \mathrm{SD}$ & $\mathrm{X} \pm \mathrm{SD}$ & $\mathrm{X} \pm \mathrm{SD}$ & $\mathrm{X} \pm \mathrm{SD}$ & $\mathrm{X} \pm \mathrm{SD}$ \\
\hline & \multicolumn{5}{|c|}{$0^{\text {th }}$ month } \\
\hline Control & $1336 \pm 441^{\mathrm{a}, \mathrm{A}}$ & $439 \pm 92^{\mathrm{a}, \mathrm{A}}$ & $0.34 \pm 0.04^{\mathrm{a}, \mathrm{A}}$ & $25 \pm 9.3^{\mathrm{a}, \mathrm{A}}$ & $223 \pm 35.5^{\mathrm{a}, \mathrm{A}}$ \\
\hline AP40 & $1010 \pm 175^{\mathrm{a}, \mathrm{A}}$ & $373 \pm 35^{\mathrm{a}, \mathrm{A}}$ & $0.37 \pm 0.03^{\mathrm{a}, \mathrm{A}}$ & $19 \pm 2.8^{\mathrm{a}, \mathrm{A}}$ & $150 \pm 24.3^{\mathrm{b}, \mathrm{A}}$ \\
\hline AP50 & $444 \pm 78^{\mathrm{b}, \mathrm{A}}$ & $231 \pm 28^{\mathrm{b}, \mathrm{A}}$ & $0.54 \pm 0.03^{\mathrm{b}, \mathrm{A}}$ & $9.0 \pm 1.2^{\mathrm{b}, \mathrm{A}}$ & $84 \pm 14.6^{\mathrm{c}, \mathrm{A}}$ \\
\hline AP60 & $599 \pm 231^{\mathrm{c}, \mathrm{A}}$ & $267 \pm 62^{\mathrm{b}, \mathrm{A}}$ & $0.47 \pm 0.07^{\mathrm{c}, \mathrm{A}}$ & $12 \pm 2.2^{\mathrm{c}, \mathrm{A}}$ & $91 \pm 6.6^{\mathrm{c}, \mathrm{A}}$ \\
\hline AP80 & $429 \pm 160^{\mathrm{b}, \mathrm{A}}$ & $230 \pm 65^{\mathrm{b}, \mathrm{A}}$ & $0.55 \pm 0.05^{\mathrm{b}, \mathrm{A}}$ & $9.2 \pm 2.2^{\mathrm{b}, \mathrm{A}}$ & $66 \pm 13.9^{\mathrm{d}, \mathrm{A}}$ \\
\hline \multirow[t]{2}{*}{ AP100 } & $61 \pm 20^{\mathrm{d}, \mathrm{A}}$ & $61 \pm 19^{\mathrm{c}, \mathrm{A}}$ & $0.65 \pm 0.02^{\mathrm{d}, \mathrm{A}}$ & - & - \\
\hline & \multicolumn{5}{|c|}{$4^{\text {th }}$ month } \\
\hline Control & $6016 \pm 640^{\mathrm{a}, \mathrm{B}}$ & $1434 \pm 331^{\mathrm{a}, \mathrm{B}}$ & $0.28 \pm 0.04^{\mathrm{a}, \mathrm{B}}$ & $101 \pm 10.2^{\mathrm{a}, \mathrm{B}}$ & $674 \pm 111^{\mathrm{a}, \mathrm{B}}$ \\
\hline AP40 & $4322 \pm 488^{\mathrm{b}, \mathrm{B}}$ & $1188 \pm 99^{\mathrm{a}, \mathrm{B}}$ & $0.28 \pm 0.01^{\mathrm{a}, \mathrm{B}}$ & $73 \pm 7.8^{\mathrm{b}, \mathrm{B}}$ & $394 \pm 21^{\mathrm{b}, \mathrm{A}}$ \\
\hline AP50 & $2358 \pm 446^{\mathrm{c}, \mathrm{B}}$ & $712 \pm 111^{\mathrm{b}, \mathrm{B}}$ & $0.30 \pm 0.01^{\mathrm{a}, \mathrm{B}}$ & $40 \pm 7.4^{\mathrm{c}, \mathrm{B}}$ & $240 \pm 51^{\mathrm{c}, \mathrm{B}}$ \\
\hline AP60 & $2984 \pm 406^{\mathrm{d}, \mathrm{B}}$ & $941 \pm 62^{\mathrm{c}, \mathrm{B}}$ & $0.32 \pm 0.06^{\mathrm{a}, \mathrm{B}}$ & $52 \pm 3.8^{\mathrm{d}, \mathrm{B}}$ & $280 \pm 7.6^{\mathrm{c}, \mathrm{d}, \mathrm{B}}$ \\
\hline AP80 & $2068 \pm 272^{\mathrm{c}, \mathrm{B}}$ & $644 \pm 65^{\mathrm{b}, \mathrm{B}}$ & $0.31 \pm 0.01^{\mathrm{a}, \mathrm{B}}$ & $35 \pm 4.0^{\mathrm{c}, \mathrm{B}}$ & $201 \pm 21^{\mathrm{c}, \mathrm{d}, \mathrm{B}}$ \\
\hline \multirow[t]{2}{*}{ AP100 } & $506 \pm 128^{\mathrm{e}, \mathrm{B}}$ & $297 \pm 52^{\mathrm{e}, \mathrm{B}}$ & $0.59 \pm 0.05^{\mathrm{b}, \mathrm{B}}$ & $30 \pm 10.3^{\mathrm{c}, \mathrm{B}}$ & $64 \pm 14^{\mathrm{e}, \mathrm{B}}$ \\
\hline & \multicolumn{5}{|c|}{$8^{\text {th }}$ month } \\
\hline Control & $9958 \pm 960^{\mathrm{a}, \mathrm{C}}$ & $3032 \pm 548^{\mathrm{a}, \mathrm{C}}$ & $0.30 \pm 0.02^{\mathrm{a}, \mathrm{B}}$ & $188 \pm 39.8^{\mathrm{a}, \mathrm{C}}$ & $2177 \pm 410^{\mathrm{a}, \mathrm{C}}$ \\
\hline AP40 & $10532 \pm 662^{\mathrm{b}, \mathrm{C}}$ & $3322 \pm 368^{\mathrm{a}, \mathrm{C}}$ & $0.32 \pm 0.02^{\mathrm{a}, \mathrm{C}}$ & $187 \pm 11.4^{\mathrm{a}, \mathrm{C}}$ & $1942 \pm 115^{\mathrm{a}, \mathrm{B}}$ \\
\hline AP50 & $4990 \pm 687^{c, C}$ & $1778 \pm 221^{\mathrm{b}, \mathrm{C}}$ & $0.36 \pm 0.01^{\mathrm{b}, \mathrm{C}}$ & $95 \pm 7.7^{\mathrm{b}, \mathrm{c}, \mathrm{C}}$ & $1036 \pm 119^{\mathrm{b}, \mathrm{C}}$ \\
\hline AP60 & $5716 \pm 687^{\mathrm{d}, \mathrm{C}}$ & $1904 \pm 196^{\mathrm{b}, \mathrm{C}}$ & $0.33 \pm 0.01^{\mathrm{a}, \mathrm{B}}$ & $103 \pm 4.7^{\mathrm{b}, \mathrm{c}, \mathrm{C}}$ & $1033 \pm 51^{\mathrm{b}, \mathrm{C}}$ \\
\hline AP80 & $4762 \pm 391^{\mathrm{c}, \mathrm{C}}$ & $1720 \pm 143^{\mathrm{b}, \mathrm{C}}$ & $0.36 \pm 0.00^{\mathrm{b}, \mathrm{C}}$ & $87 \pm 5.7^{\mathrm{b}, \mathrm{C}}$ & $775 \pm 58^{\mathrm{c}, \mathrm{C}}$ \\
\hline \multirow[t]{2}{*}{ AP100 } & $1122 \pm 64^{\mathrm{e}, \mathrm{C}}$ & $705 \pm 15^{\mathrm{c}, \mathrm{C}}$ & $0.63 \pm 0.03^{\mathrm{c}, \mathrm{B}}$ & $26 \pm 1.9^{\mathrm{d}, \mathrm{B}}$ & $158 \pm 13^{\mathrm{d}, \mathrm{C}}$ \\
\hline & \multicolumn{5}{|c|}{$12^{\text {th }}$ month } \\
\hline Control & $9346 \pm 875^{\mathrm{a}}$ & $3654 \pm 523^{\mathrm{a}, \mathrm{C}}$ & $0.39 \pm 0.03^{\mathrm{a}, \mathrm{C}}$ & $210 \pm 23.4^{\mathrm{a}, \mathrm{C}}$ & $3027 \pm 291^{\mathrm{a}, \mathrm{D}}$ \\
\hline AP40 & $10850 \pm 508^{b}$ & $3872 \pm 298^{\mathrm{a}, \mathrm{C}}$ & $0.35 \pm 0.01^{\mathrm{a}, \mathrm{C}}$ & $203 \pm 11.6^{\mathrm{a}, \mathrm{C}}$ & $2234 \pm 225^{\mathrm{a}, \mathrm{B}}$ \\
\hline AP50 & $4414 \pm 684^{\mathrm{c}}$ & $1915 \pm 234^{\mathrm{b}, \mathrm{C}}$ & $0.42 \pm 0.01^{\mathrm{a}, \mathrm{b} C}$ & $91 \pm 9.1^{\mathrm{b}, \mathrm{C}}$ & $982 \pm 214^{\mathrm{c}, \mathrm{C}}$ \\
\hline AP60 & $6246 \pm 840^{\mathrm{d}}$ & $2322 \pm 395^{\mathrm{b}, \mathrm{C}}$ & $0.42 \pm 0.03^{\mathrm{a}, \mathrm{b}, \mathrm{C}}$ & $117 \pm 21.0^{\mathrm{c}, \mathrm{C}}$ & $1342 \pm 319^{\mathrm{c}, \mathrm{C}}$ \\
\hline AP80 & $3540 \pm 113^{\mathrm{c}}$ & $1452 \pm 57^{\mathrm{c}, \mathrm{D}}$ & $0.41 \pm 0.02^{\mathrm{a}, \mathrm{b}, \mathrm{D}}$ & $69 \pm 3.2^{\mathrm{d}, \mathrm{D}}$ & $638 \pm 24^{\mathrm{d}, \mathrm{D}}$ \\
\hline AP100 & $1584 \pm 192^{\mathrm{e}}$ & $1164 \pm 46^{\mathrm{d}, \mathrm{D}}$ & $0.74 \pm 0.06^{\mathrm{c}, \mathrm{C}}$ & $37 \pm 3.3^{\mathrm{e}, \mathrm{D}}$ & $187 \pm 49^{\mathrm{e}, \mathrm{C}}$ \\
\hline
\end{tabular}

$\mathrm{X}$ : average; SD: standard deviation; $\mathrm{G}_{0}(\mathrm{~Pa})$ : initial storage modulus; $\mathrm{G}_{0}(\mathrm{~Pa})$ : initial loss modulus; DF: damping factor $\mathrm{G}^{\prime \prime} / \mathrm{G}^{\prime} ; \mathrm{t}_{\mathrm{LVE}}(\mathrm{Pa})$ : shear stress at the end of linear viscoelastic range; $\mathrm{t}_{\mathrm{CO}}(\mathrm{Pa})$ : shear stress at the crossover point $\mathrm{A}, \mathrm{B}, \mathrm{C}$ : comparison of samples with the same AP content at consecutive storage times $\left(0-4^{\text {th }}\right.$ month, $4-8^{\text {th }}$ month and $8-12^{\text {th }}$ month)

a, b, c: comparison of samples with different AP content to the control sample values at the same storage time $\left(0^{\text {th }}\right.$, $4^{\text {th }}, 8^{\text {th }}$ and $12^{\text {th }}$ month)

The same letter means there is no significant difference between the samples at $95 \%$ probability level 
DF increased with increasing amount of AP addition. Damping factor is a dimensionless value, denotes the relative effects of viscous and elastic components on viscoelastic behaviour (Sundaram \& Mehmet, 2000). Increasing DF refers to change of viscoelastic solid towards viscoelastic liquid behaviour.

$\operatorname{LVE}\left(\tau_{\mathrm{LVE}}\right)$ and crossover $\left(\tau_{\mathrm{CO}}\right)$ decreased with increasing AP content of bakery jams. LVE value indicates the stability against deformation and crossover indicates the shear stress at which the sample turns from viscoelastic solid to viscoelastic liquid (MEzGER, 2006). However, LVE is the indicator of structural changes in function of shear stress, crossover is also considered to be a good indicator when the structure is ruptured and the flow behaviour has started to be a good predicator for sensory "initial firmness" (GUGGISBERG et al., 2009).

Bakery jams containing AP powder showed weaker gel-like behaviour compared to the reference bakery jam containing industrial bakery pectin as indicated by the lower $\mathrm{G}_{0}$, and $\mathrm{G}^{\prime}{ }_{0}$ values, higher DF values, and lower stability (lower LVE and crossover). However, amplitude sweep parameters of $\mathrm{AP}_{40}$ did not show significant difference compared to control suggesting that $40 \%$ of pectin could be replaced by apple pomace powder without changing rheological characteristics of bakery jams. Parameters of $\mathrm{AP}_{50}$ and $\mathrm{AP}_{80}$ samples did not show significant differences, while in case of $\mathrm{AP}_{60}$ samples higher values were observed. $\mathrm{AP}_{100}$ sample prepared without pectin proved to be the weakest gel and showed very different behaviour compared to other samples. Results suggested that not only the amount of AP but its interactions with pectin influence the rheological properties of jams.

\subsection{Effect of storage}

During 12 months of storage, amplitude sweep rheograms of all bakery jams shifted towards higher shear stress values, while G' and G" values increased (Fig. 2.). There was no significant change in rheograms between the $8^{\text {th }}$ and $12^{\text {th }}$ months. During the 12 months of storage, the differences between rheograms of bakery jams with different AP levels decreased (Figs 1A and 1B.)

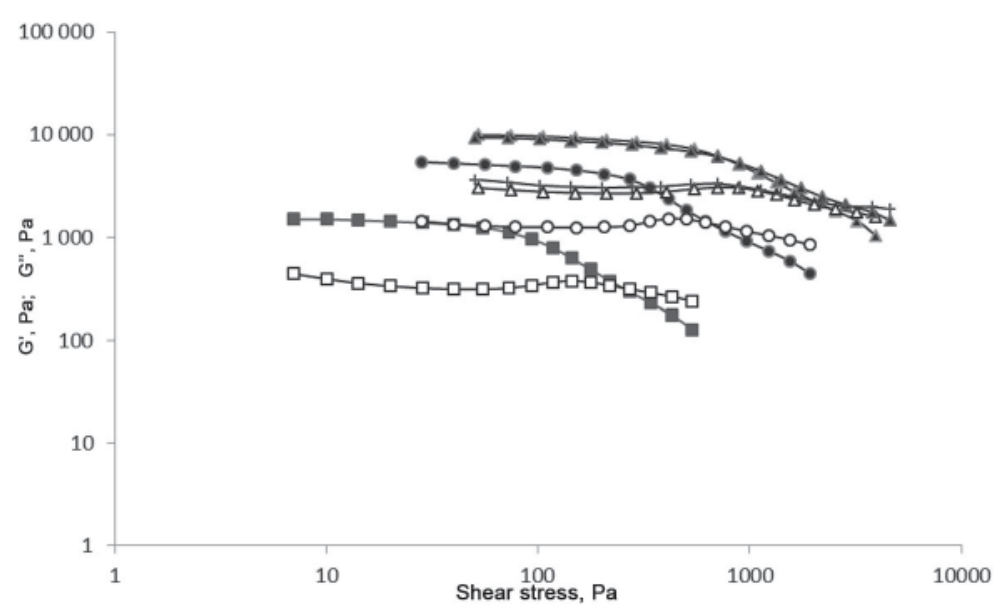

Fig. 2. Changes of amplitude sweep rheograms of control (without apple pomace powder) bakery jam during 12 months of storage. - $\square$ : G' $0^{\text {th }}$ month; $\square:$ G' $0^{\text {th }}$ month; $\bullet$ G' $4^{\text {th }}$ month; O: G" $4^{\text {th }}$ month; $\mathbf{\Delta}: G^{\prime} 8^{\text {th }}$ month; $\Delta: G^{\prime \prime} 8^{\text {th }}$ month; $\times: G^{\prime} 12^{\text {th }}$ month, $+G^{\prime \prime} 12^{\text {th }}$ month 
All parameters investigated: $\mathrm{G}_{0}{ }_{0} \mathrm{G}{ }_{0}, \mathrm{LVE}$, and crossover values had increasing tendency during the first 8 months of storage and showed no significant changes during the last four months (Table 2).

DF showed slight changes but had decreasing tendency until the fourth month and then started to increase. At the end of storage, damping factor had similar values compared to the initial, except for sample $\mathrm{AP}_{100}$ that had higher DF value (0.744) than at the beginning $(0.652)$.

Results indicate that stiffness, gel strength, and gel stability of bakery jams increased during storage. Gel strength of jams can be influenced by changes of gel structure, changes of water binding forms of hydrocolloids, or by water loss due to syneresis.

\section{Conclusions}

Apple pomace powder produced by a simple drying method proved to be suitable for replacing pectin in bakery jams up to $40 \%$. AP containing bakery jams showed good storage stability. Using AP as a gelling agent increases the nutritional value of jams because of its high antioxidant content, increases the marketing value of jams by decreasing the amount of food additives, and also decreases the waste production of industrial apple processing technologies.

The authors gratefully thank Gábor Komlós for help and technical assistance in the laboratory.

\section{References}

Baker, R.A., Berry, N., Hui, Y.H. \& Barrett D.M. (2005): Fruit preserves and jams. -in: Barrett, D.M., Somogyi, L. \& Ramaswamy, H.S. Processing fruits. $2^{\text {nd }}$ ed., CRC Press, Boca Raton, FL, USA, pp. 113-127.

Christensen, S.H., Mathiesen, H.P. \& Hansen, K.M. (2008): Pectin for heat stable bakery jams. United States Patent Application Publication. Pub. No.: US 2008/0166465 A1

Codex Alimentarius (2009): Standard for jams, jellies and marmalades. Codex standard 296: Website: http://www. codexalimentarius.org/standards/list-of-standards/

Favela-Torres, E., Volke, S.T. \& Viniegra, G.G. (2006): Production of hydrolytic depolymerising pectinases. Food Technol. Biotechnol., 44, 221-227.

Figura, O.L. \& Teixeira, A.A. (2007): Food physics-Physical properties-Measurement and application. Springer, Berlin, pp. 186-187.

Foo, L.Y. \& Lu, Y. (1999): Isolation and identification of procyanidins in apple pomace. Food Chem., 64, 511-518.

Guggisberg, D., Cuthbert-Steven, J., Piccinah, P., Buetikofer, U. \& Eberhard, P. (2009): Rheological, microstructural and sensory characterization of low-fat and whole milk set yogurt as influenced by inulin addition. Int. Dairy J., 19, 107-115.

Gunasekaran, S. \& Mehmet, M.A. (2000): Dynamic oscillatory shear testing of foods - selected applications. Trends Food Sci. Tech., 11, 115-127.

Javanmard, M. \& Endan, J. (2010): A survey on rheological properties of fruit jams. Int. J. Chem. Eng. Appl., 1, (1), 31-37.

JuHÁsz, R., ZEKe, I.Cs., BALLA, Cs. \& BARTA, J. (2011): Oszcillációs reometria alkalmazása azélelmiszervizsgálatokban (Application of oscillatory rheometry in food analyses). Élelmiszervizsgálati Közlemények, 57, 169-180.

Mezger, T.G. (2006): The rheology handbook. Vincentz Network, Hannover, pp. 124-159.

Nishinari, K.N. (2009): Texture and rheology in food and health. Food Sci. Technol. Res., 15, 99-106.

Royer, G., Madieta, E., Symoneaux, R. \& Jourjon, F. (2006): Preliminary study of the production of apple pomace and quince jelly. LWT - Food Sci. Technol., 39, 1022-1025. 
Schieber, A., Hilt, P., Streker, P., Endress, H.U., Rentschler, C. \& Carle, R. (2003): A new process for the combined recovery of pectin and phenolic compounds from apple pomace. Innov. Food Sci. Emerg., 4 (1), 99-107.

Shojaosadati, S. A., \& Babaeipour, V. (2002): Citric acid production from apple pomace in multi-layer packed bed solid-state bioreactor. Proc. Biochem., 37, 909-914.

Sundaram, G. \& Mehmet, M.A.K (2000): Dynamic oscillatory shear testing of foods-Selected applications. Trends Food Sci. Tech., 11, 115-127.

Vajda, Á., Zeke, I.Cs., JuhÁsz, R., Barta, J. \& Balla, Cs. (2013): Effect of acid whey concentrate on thermophysical properties of milk-based ice cream. Acta Alimentaria, 42 (Suppl.), 107-115. 